\title{
Popcorn is more satiating than potato chips in normal-weight adults
}

\author{
Von Nguyen', Lisa Cooper', Joshua Lowndes', Kathleen Melanson², Theodore J Angelopoulos ${ }^{3}$,
} James M Rippe ${ }^{4}$ and Kristin Reimers ${ }^{5^{*}}$

\begin{abstract}
Background: Strategies that may increase compliance to reduced energy intakes are needed to reduce the health burden of obesity. Conflicting evidence exists regarding the effects of snacking on satiety and energy intake.

Methods: This study compared short-term satiety from two common snack foods, low fat popcorn or potato chips. Using a counterbalanced within-subject design, 35 normal weight non-smoking participants (17 men, 18 women) ages 20-50 years (mean age $33 \pm 11, \mathrm{BMl} 23 \pm 2 \mathrm{~kg} / \mathrm{m}^{2}$ ) consumed four conditions each: $200 \mathrm{~mL}$ of water (control), one cup (4 g, $15 \mathrm{kcal})$ popcorn, 6 cups ( $27 \mathrm{~g}, 100 \mathrm{kcal})$ popcorn, and one cup $(28 \mathrm{~g}, 150 \mathrm{kcal})$ potato chips, each with $200 \mathrm{~mL}$ water. Participants rated their hunger, satisfaction, prospective consumption, and thirst on $100 \mathrm{~mm}$ visual analogue scales 30 minutes after commencement of snack consumption. In addition, post-snack energy intake from an ad libitum meal (amount served less amount remaining) was measured, and the test food and meal combined energy intake and energy compensation were calculated.
\end{abstract}

Results: Participants expressed less hunger, more satisfaction, and lower estimates of prospective food consumption after six cups of popcorn compared to all other treatments $(P<0.05)$. Energy compensation was $220 \% \pm 967 \%, 76 \% \pm 143 \%$ and $42 \% \pm 75 \%$ after one cup popcorn, six cups popcorn and one cup potato chips, respectively. Combined energy intake was significantly greater $(P<0.01)$ during the potato chips condition (803 $\pm 277 \mathrm{kcal})$ compared to control $(716 \pm 279 \mathrm{kcal})$ or popcorn conditions $(698 \pm 286 \mathrm{kcal}$ for one cup and $739 \pm 294$ kcal for six cups). Combined energy intakes from both popcorn conditions were not significantly different than control ( $p>0.05)$.

Conclusion: Popcorn exerted a stronger effect on short-term satiety than did potato chips as measured by subjective ratings and energy intake at a subsequent meal. This, combined with its relatively low calorie load, suggests that whole grain popcorn is a prudent choice for those wanting to reduce feelings of hunger while managing energy intake and ultimately, body weight.

Keywords: Popcorn, Satiety, Hunger, Fullness, Snack, Energy intake, Energy compensation, Weight management

\section{Introduction}

To help quell the burgeoning obesity epidemic, researchers have devoted considerable effort to understand functional attributes of foods and nutrients that may influence energy intake. Satiety, the sensations that determine the intermeal period of fasting [1], is affected by many variables including food volume, weight, energy, macronutrient content, physical form, type, and variety [1-8]. The impact of satiety on long term energy balance

\footnotetext{
*Correspondence: kristin.reimers@conagrafoods.com

${ }^{5}$ ConAgra Foods, 5 ConAgra Drive, Omaha, NE 68102, USA

Full list of author information is available at the end of the article
}

and ultimately weight management is debated [9], but satiety is nonetheless a measurable construct that reliably influences ingestive behaviors, thus creating a connection to energy balance and ultimately body weight [10-13].

Understanding the relationship of snack foods to satiety and energy balance is important because snack foods now contribute approximately one fourth of U.S. adults' total daily energy intake, similar to that of lunch and greater than the energy contribution of breakfast [14]. Snack foods are typically described as being more energy dense and less nutrient dense than foods consumed at

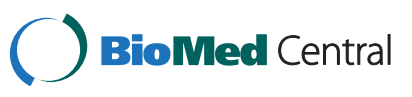


meals $[15,16]$, but this is not necessarily the case for snack foods such as vegetables, fruits or whole grain foods such as popcorn. The heterogeneity of snack foods, and the potentially diverse impact of snacks on eating behaviors and on the overall diet pattern has not received a great deal of attention. Because snacking has become an increasingly important segment of the American eating pattern, understanding the attributes of various snacks has become more relevant. The purpose of the current research was to compare the effects on satiety of two snacks, popcorn and potato chips. Potato chips are the most commonly consumed savory snack food in America [17], eaten approximately 50 times per person annually [18]. Popcorn is the 10th ranked savory snack in the U.S., eaten approximately nine times per person annually [18], and has been shown to have a beneficial association with whole grain and fiber intake among those who consume it [19].

\section{Methods}

Participants

Thirty five healthy non-smoking females $(\mathrm{n}=18)$ and males $(n=17)$ ages $20-50$ years (mean age $33 \pm 11$ ) with BMI $18-25 \mathrm{~kg} / \mathrm{m}^{2}$ (mean BMI $23 \pm 2$ ) were recruited primarily by newspaper advertisement to voluntarily participate in the study that will provide data on the effects on satiety (appetite) after consuming popcorn and potato chips in varying amounts. Interested individuals were screened via a phone interview for exclusion criterion that included allergy to or disliking of the test foods, smoking, prescription medications, special diet, diabetes, gastrointestinal disorders, eating disorders, and pregnancy, lactation, or trying to become pregnant. Prospective participants were also screened for dietary restraint (score $>10$ was disqualifying), disinhibition and perceived hunger during their initial visit by administration of the Eating Inventory [20]. Using standard procedures, body mass and height were measured (Scale Tronix, Wheaton, IL), then BMI calculated to confirm prospective participants met the BMI criteria. The Florida Hospital Institutional Review Board, Celebration Florida, approved the study and all participants provided written informed consent at the research center before beginning the study.

\section{Design/Protocol}

Using a within-subject counterbalanced design, participants consumed each of four test foods 30 minutes prior to an ad libitum meal. Test days were scheduled at least three days apart and all participants completed four treatments within 60 days. Participants were instructed to refrain from alcohol consumption and exercise the day prior to each test day and to fast for 12 hours overnight. Upon arriving at the research facility at 9:00 a.m., participants were seated in secluded rooms where they stayed until approximately 1:00 p.m. Shortly after arrival, the participants consumed a $500 \mathrm{kcal}$ (men) or $400 \mathrm{kcal}$ (women) standard meal within 15 minutes, consisting of 44 g ready-to-eat cereal, $462 \mathrm{~g}$ whole milk, and $130 \mathrm{~g}$ orange juice for men and $33 \mathrm{~g}$ ready-to-eat cereal, $371 \mathrm{~g}$ whole milk and $130 \mathrm{~g}$ orange juice for women. Caloric distribution for the meal was 55\% carbohydrate, 15\% protein and $30 \%$ fat. One cup $(240 \mathrm{~mL})$ of coffee or tea was provided for those who routinely consumed these beverages in the morning. Participants were instructed to consume the entire meal, and all were compliant in doing so.

On the first visit, participants also received a $500 \mathrm{~mL}$ bottle of water, which they were allowed to consume ad libitum between the morning meal and one hour prior to consuming the test food. The amount consumed was provided at all subsequent visits. Prior to receiving the test food, participants were allowed to sit quietly and to read, but were not allowed access to any materials that contained reference to food, eating, dieting, or body weight. Thirty minutes prior to the ad libitum meal, participants were served the relevant test food and were required to consume it within 15 minutes. The ad libitum meal was served at 12:30 p.m. and participants were invited to eat as much as they liked with no time restriction.

\section{Test foods and Ad libitum meal}

The control condition was $200 \mathrm{~mL}$ of water. The test conditions consisted of one cup (4 g, $15 \mathrm{kcal})$ or six cups (27 g, $100 \mathrm{kcal}$ ) of $94 \%$ fat free microwave popcorn, or one cup (28 g, $150 \mathrm{kcal})$ of potato chips, all served with $200 \mathrm{~mL}$ water. These quantities were chosen to compare both equal volumes (one cup) of popcorn and potato chips as well as labeled serving sizes. The labeled individual serving sizes on these packaged products were 27 $\mathrm{g}$ for a $100 \mathrm{kcal}$ mini bag of popcorn (approximately six cups) and $28 \mathrm{~g}$ for one serving (approximately one cup) of potato chips. The ad libitum meal consisted of a generous pre-weighed portion of commercially prepared macaroni and cheese and water $(500 \mathrm{~mL})$. Participants were invited to eat as much as they wanted and were invited to request more if they so desired. The macronutrient energy distribution and fiber content of the test foods and ad libitum meal are shown in Table 1.

\section{Measures}

Satiety was measured using visual analogue scales (VAS), as well as measures of subsequent energy intake and energy compensation [21]. Participants rated hunger, satisfaction, how much food they thought they could eat (prospective consumption) and thirst on $100 \mathrm{~mm}$ VAS anchored with extreme ratings of "not at all" vs. 
Table 1 Nutrient composition of test foods and ad libitum meal as served

\begin{tabular}{|c|c|c|c|c|c|}
\hline & $\begin{array}{c}200 \mathrm{~mL} \\
\text { water }\end{array}$ & $\begin{array}{l}1 \text { cup popcorn + } \\
200 \mathrm{~mL} \text { water }\end{array}$ & $\begin{array}{l}6 \text { cups popcorn + } \\
200 \mathrm{~mL} \text { water }\end{array}$ & $\begin{array}{l}1 \text { cup potato chips + } \\
200 \mathrm{~mL} \text { water }\end{array}$ & $\begin{array}{l}\text { Macaroni and } \\
\text { cheese entrée }\end{array}$ \\
\hline Food Weight, g & - & 4 & 27 & 28 & 645 \\
\hline Kcal & 0 & 15 & 100 & 150 & 1000 \\
\hline Fat, g & 0 & $<1$ & 1.5 & 9.5 & 49 \\
\hline Fat, \% kcal & 0 & 14 & 14 & 57 & 44 \\
\hline Carbohydrate, g & 0 & 3 & 21 & 15 & 97 \\
\hline Carbohydrate, \% kcal & 0 & 74 & 74 & 40 & 39 \\
\hline Fiber, $g$ & 0 & 0.8 & 3 & 1 & 6 \\
\hline Protein, $\mathrm{g}$ & 0 & $<1$ & 3 & 1 & 43 \\
\hline Protein, \% kcal & 0 & 12 & 12 & 3 & 17 \\
\hline
\end{tabular}

"extremely" to describe how hungry, satisfied or thirsty they were and "nothing" or "vast quantities" to describe how much they could eat. Palatability was assessed using VAS with ratings for extremes of pleasant, salty, texture, bitter and taste. Participants received instruction for and practiced completing the VAS prior to the study. At each of the four trials, palatability was rated after the first bite of the test food and satiety rated 30 minutes later, immediately before access to the ad libitum meal. Intake of the ad libitum meal was calculated by weighing to the nearest 1.0 gram the starting meal weight and subtracting the remaining food weight (Tanita scale model $1458 \mathrm{~N}$, Arlington Heights, IL). Energy ( $\mathrm{kcal} / \mathrm{g}$ ) of the macaroni and cheese was based on labeled kcal content. Combined energy intake was determined by summing the energy intake of the test food plus the ad libitum meal. Percent energy compensation of the test foods at the subsequent ad libitum meal was calculated as: (meal kcal intake during control condition - meal kcal intake during test condition) / test food kcal content x 100 .

\section{Statistical analysis}

One way ANOVA with repeated measures was used to test differences across the treatments for each dependent variable. Pairwise comparisons were made when necessary via dependent t-tests, applying the Bonferroni adjustment. Statistical significance was set at $\mathrm{p}<0.05$.

\section{Results}

Compared to control, all three test conditions resulted in significantly less hunger, more satisfaction, lower estimates of prospective food consumption, and more thirst $(\mathrm{p}<0.01$, Table 2$)$. Six cups of popcorn produced greater satiety ratings compared to both one cup of popcorn and one cup of potato chips $(\mathrm{p}<0.05)$.

Table 2 VAS palatability and satiety ratings for control, popcorn and potato chip conditions

\begin{tabular}{|c|c|c|c|c|}
\hline & \multirow[t]{2}{*}{ Water control } & \multirow{2}{*}{$\frac{\text { Popcorn }}{\text { One cup }}$} & \multirow{2}{*}{$\frac{\text { Popcorn }}{\text { Six cups }}$} & \multirow{2}{*}{$\frac{\text { Potato chips }}{\text { One cup }}$} \\
\hline & & & & \\
\hline \multicolumn{5}{|c|}{ Rating, mm mean \pm standard deviation } \\
\hline How pleasant is this food? & $21.7 \pm 25.9$ & $51.3 \pm 27.1^{* * *}$ & $57.7 \pm 23.2^{* * *}$ & $51.4 \pm 21.5^{* * *}$ \\
\hline How salty is this food? & $4.2 \pm 10.7$ & $49.2 \pm 23.0^{* * *}+十+$ & $57.9 \pm 26.8^{* * *}$ & $67.2 \pm 26.3^{* * *}$ \\
\hline How bitter is this food? & $2.6 \pm 3.4$ & $11.6 \pm 14.4^{* *}$ & $10.8 \pm 15.7^{* *}$ & $8.9 \pm 13.2^{* *}$ \\
\hline How much do you like the texture of this food? & $31.3 \pm 26.7$ & $59.4 \pm 25.6^{* * *}$ & $58.2 \pm 21.5^{* * *}$ & $56.7 \pm 17.9^{* * *}$ \\
\hline How much do you like the taste of this food? & $17.3 \pm 23.7$ & $56.8 \pm 25.7^{* * *}$ & $59.4 \pm 22.9^{* * *}$ & $57.6 \pm 22.3^{* * *}$ \\
\hline How hungry are you? & $73.5 \pm 18.7$ & $63.9 \pm 17.4^{* * *}+十+$ & $47.7 \pm 20.5^{* * *}$ & $60.1 \pm 21.9^{* * *+十}$ \\
\hline How satisfied are you? & $22.4 \pm 17.0$ & $36.1 \pm 19.3^{* * *}+\dagger$ & $47.9 \pm 20.5^{* * *}$ & $39.6 \pm 21.9^{* * *} \dagger$ \\
\hline How much could you eat? & $71.7 \pm 16.1$ & $63.3 \pm 18.0^{* * *}+\dagger$ & $49.3 \pm 19.5^{* * *}$ & $57.9 \pm 20.1^{* * *} \dagger$ \\
\hline How thirsty are you? & $27.6 \pm 23.8$ & $36.4 \pm 22.6^{* *}+$ & $43.7 \pm 25.6^{* *}$ & $44.5 \pm 25.6^{* * *}$ \\
\hline
\end{tabular}

** Significantly different from water $(\mathrm{P}<0.01)$.

*** Significantly different from water $(P<0.001)$.

† Significantly different from six cups popcorn $(P<0.05)$.

†† Significantly different from six cups popcorn $(P<0.01)$.

t†† Significantly different from six cups of popcorn $(P<0.001)$.

The visual analog scales were $100 \mathrm{~mm}$ in length. How pleasant, salty and bitter scales were anchored by "not at all" and "extremely" and the texture and taste scales were anchored by "dislike extremely" and "like extremely." The satiety VAS was measured 30 minutes after commencement of test food. How hungry, satisfied, and thirsty scales were anchored by "not and all" and "extremely." How much could you eat scale was anchored by "nothing" and "vast quantities". 
Ad libitum meal consumption was significantly decreased after consumption of six cups of popcorn and one cup of potato chips compared to control (Table 3). The combined energy intake (test food plus meal) of each popcorn condition was not different from control and significantly less than $(\mathrm{p}<0.01)$ the combined energy intake of the potato chips condition. The extent of energy compensation from potato chips was $42 \% \pm 75 \%$ $(63 \pm 112 \mathrm{kcal})$ compared to $76 \% \pm 143 \%(76 \pm 143 \mathrm{kcal})$ for six cups popcorn and $220 \% \pm 967 \%(33 \pm 145 \mathrm{kcal})$ for one cup popcorn.

\section{Discussion}

These data indicate that popcorn resulted in greater satiety than potato chips. The six cup popcorn condition exhibited greater satiety than potato chips based on the outcome measures of VAS ratings and combined energy intake. One cup popcorn (15 kcal) did not elicit stronger VAS responses than one cup potato chips (150 kcal), but did elicit similar VAS responses (not statistically different) despite the 10-fold energy difference, suggesting that $15 \mathrm{kcal}$ of popcorn was as satiating as $150 \mathrm{kcal}$ of potato chips. Additionally, the one cup popcorn condition resulted in less combined energy intake and incomplete mean energy compensation. These data in their totality indicate that both popcorn conditions resulted in greater satiety than potato chips.

Several attributes of popcorn may contribute to its satiating effect at a relatively low energy level, for example, its low energy density [3]. The energy density of the $94 \%$ fat free popcorn $(3.7 \mathrm{kcal} / \mathrm{g})$ is $31 \%$ lower than that of potato chips $(5.4 \mathrm{kcal} / \mathrm{g})$. Volume is likely another satiety-promoting quality of popcorn. Starch expansion during the popping process produces a foam-like matrix with a large surface-area to mass ratio. This trait, combined with popcorn's irregular shape, leads to a food with a high volume per unit weight. High volume, due to incorporating air into food and due to irregular shape, has been shown to increase satiety $[2,4,22]$. Additionally, the proportionality of macronutrients may contribute to satiety, as prior research has shown that fat is less satiating than carbohydrate or protein [23-25]. The higher fat content of potato chips may have contributed to lower VAS scores and less compensation. Finally, the participants were not blinded to the volume or appearance of the snacks, so the visual differences among the snacks may have influenced perceptions of hunger, satisfaction and prospective consumption. Any combination of these characteristics of popcorn could potentially contribute to its effect on short-term satiety despite the relatively low calorie provision.

Snacks that offer relatively higher levels of satiety may be beneficial for weight management provided the snack does not contribute to greater overall energy intake. One of the primary issues that has been identified in relationship to snacking, satiety and energy intake is the inability to fully compensate for the energy consumed as snacks $[15,26,27]$. Evidence shows that snacks consumed in a non-hungry state do not impact satiety or reduce energy intake at the subsequent meals [15,26-30] and cross-sectional and longitudinal studies suggest that snacking is associated with weight gain and or obesity $[16,31,32]$. Energy dense, highly palatable foods such as cookies, cakes, desserts, and candies are associated with higher energy intakes in obese adults [16]. In contrast, compensation for popcorn was observed in the current study, resulting in overall energy intake not different from having no snack. This finding is supported by previous population-based research that shows popcorn consumption is not related to increased body mass index [19]. In addition, longitudinal [6] and weight loss interventions [33-36] indicate that snacking has a neutral or positive effect on energy intake or body mass index. For example, provision of up to three snacks daily as part a weight loss diet had a neutral effect on weight change [33-35].

The inconsistency in results about snacking may be attributed to many variables such as inconsistent definition of a snack, whether the snack is consumed during a non-hungry state, the timing of the snack around the

Table 3 Combined energy intakes during control, popcorn and potato chip conditions

\begin{tabular}{|c|c|c|c|c|}
\hline & Water control & Popcorn & Popcorn & Potato chips \\
\hline & & One cup & Six cups & One cup \\
\hline \multicolumn{5}{|c|}{ mean \pm standard deviation } \\
\hline Water, ml & $338 \pm 194$ & $351 \pm 256$ & $333 \pm 202$ & $321 \pm 196$ \\
\hline Macaroni and cheese lunch, kcal & $716 \pm 279$ & $683 \pm 286$ & $639 \pm 294+\dagger$ & $653 \pm 277+\dagger$ \\
\hline Test food, kcal & 0 & 15 & 100 & 150 \\
\hline Combined energy intake, kcal & $716 \pm 279^{* * *}$ & $698 \pm 286^{* * *}$ & $739 \pm 294^{* *}$ & $803 \pm 277$ \\
\hline Energy Compensation, kcal & & $33 \pm 145$ & $76 \pm 143$ & $63 \pm 112$ \\
\hline Energy Compensation, \% & & $220 \pm 967$ & $76 \pm 143$ & $42 \pm 75$ \\
\hline
\end{tabular}

** Significantly different from one cup potato chips $(P<0.01)$.

*** Significantly different from one cup potato chips $(P<0.001)$.

†† Significantly different from control $(P<0.01)$. 
meal, whether the snacking is part of usual intake or a reduced calorie diet, the population studied, and the attributes of the food itself (energy density, volume, macro- and micronutrient composition and physical form). The types of foods consumed as snacks are extremely broad, ranging from nutrient dense fruits, vegetables and whole grains, to energy dense desserts and confections. As such, while some snacks do not show nutrient benefit, some snacks have been shown to improve diet quality due to higher fruit, vegetable and fiber intakes $[37,38]$. Population data show that individuals who consume popcorn, compared to those who do not, have significantly greater intakes of whole grain, fiber, and magnesium [19]. To strengthen future research, the heterogeneity of snacks and snacking behaviors should be considered and controlled to better characterize the role of snacking as it relates to energy balance and weight management.

\section{Limitations and future research}

This study has several limitations and stimulates additional research questions. The generalizability of this study is limited due to the sample including only normal weight men and women less than 50 years of age. The findings may vary on overweight, obese or older adults and children. Serving the meal 30 minutes after commencement of the test food was designed to capture the satiety effects of the relatively low energy loads of the test foods (15 kcal to $150 \mathrm{kcal})$, but this relatively short time interval may not represent a typical snack-meal pattern. Thus, the results of this study support the short-term satiety attribute of popcorn relative to potato chips, but cannot be generalized to satiety, energy compensation, or energy reduction over longer periods of time.

Future research should consider testing a wide variety of snack foods, including higher fat popcorn. It would also be of interest to compare eucaloric portions of popcorn with various other snacks. One question spurred by this current study is whether a $100 \mathrm{kcal}$ portion of other commonly consumed snacks would lead to more complete energy compensation, as was observed with popcorn. Similarly, the effects of popcorn at energy loads greater than $100 \mathrm{kcal}$ are unknown. Timing of the test food before the meal is another area of interest. A study that models a typical snacking pattern would be useful to build upon the current findings. Finally, future research should be carried out for longer periods of time to ascertain whether energy compensation is maintained throughout the course of the day.

\section{Conclusion}

Foods or nutrients that enhance satiety are considered one of many factors that affect energy intake regulation
[10-12]. A snack that reduces the burden of hunger, while not increasing overall energy intake, may offer a benefit for individuals trying to maintain or achieve energy balance. In this study, low fat popcorn was shown to exert greater short-term satiety than potato chips. The satiety attribute, combined with popcorn's other favorable characteristics of being a whole grain, high fiber, nutrient dense snack, support popcorn as beneficial snack choice in the context of healthy weight management.

\section{Competing interests}

This research was supported by ConAgra Foods, Inc., makers of Orville Redenbacher and Act II popcorn. K. Reimers is an employee of ConAgra Foods.

\section{Authors contributions}

VN participated in the design of the study, carried out the dietary analysis and helped draft the manuscript. LC participated in the design of the study and carried out the dietary analysis. $J$ participated in the design of the study, supervised data entry, performed the statistical analyses, and helped draft the manuscript. KM participated in the design of the study and helped draft the manuscript. TA participated in the design of the study, had the responsibilty of the statistical analyses, and helped draft the manuscript. JR participated in the design of the study and helped draft the manuscript. KR participated in the design of the study and helped draft the manuscript. All authors read and approved the final manuscript.

\section{Acknowledgements}

The study and the writing of the manuscript was supported by ConAgra Foods.

\section{Author details}

${ }^{1}$ Rippe Lifestyle Institute, 215 Celebration Place, Celebration, FL 34747, USA. ${ }^{2}$ Department of Nutrition and Food Sciences, University of Rhode Island, Knigston, RI 02881, USA. ${ }^{3}$ Center for Lifestyle Medicine and Department of Health Professions, University of Central Florida, Orlando, FL 32816, USA.

${ }^{4}$ Rippe Lifestyle Institute, 21 N. Quinsigamond Avenue, Shrewsbury, MA 01545 , USA. ${ }^{5}$ ConAgra Foods, 5 ConAgra Drive, Omaha, NE 68102, USA.

Received: 9 April 2012 Accepted: 5 September 2012

Published: 14 September 2012

\section{References}

1. Mattes RD, Hollis J, Hayes D, Stunkard AJ: Appetite: measurement and manipulation misgivings. J Am Diet Assoc 2005, 105:S87-\$97.

2. Osterholt KM, Roe LS, Rolls BJ: Incorporation of air into a snack food reduces energy intake. Appetite 2007, 48:351-358.

3. Rolls BJ, Bell EA, Thorwart ML: Water incorporated into a food but not served with a food decreases energy intake in lean women. Am J Clin Nutr 1999, 70:448-455.

4. Rolls BJ, Bell EA, Waugh BA: Increasing the volume of a food by incorporating air affects satiety in men. Am J Clin Nutr 2000, 72:361-368.

5. Rolls BJ, Castellanos VH, Halford JC, Kilara A, Panyam D, Pelkman CL, Smith GP, Thorwart ML: Volume of food consumed affects satiety in men. Am J Clin Nutr 1998, 67:1170-1177.

6. Leidy HJ, Campbell WW: The effect of eating frequency on appetite control and food intake: brief synopsis of controlled feeding studies. J Nutr 2011, 141:154-157.

7. Oesch S, Degen L, Beglinger C: Effect of a protein preload on food intake and satiety feelings in response to duodenal fat perfusions in healthy male subjects. Am J Physiol Regul Integr Comp Physiol 2005, 289:R1042-R1047.

8. Schroeder N, Gallaher DD, Arndt EA, Marquart L: Influence of whole grain barley, whole grain wheat, and refined rice-based foods on short-term satiety and energy intake. Appetite 2009, 53:363-369.

9. Booth DA, Nouwen A: Weight is controlled by eating patterns, not by foods or drugs. Appetite 2011, 57:784-790. 
10. Bray GA, Champagne CM: Beyond energy balance: there is more to obesity than kilocalories. J Am Diet Assoc 2005, 105:S17-S23.

11. Paddon-Jones D, Westman E, Mattes RD, Wolfe RR, Astrup A, WesterterpPlantenga M: Protein, weight management, and satiety. Am J Clin Nutr 2008, 87:1558S-1561S.

12. Schoeller DA, Buchholz AC: Energetics of obesity and weight control: does diet composition matter? J Am Diet Assoc 2005, 105:S24-S28.

13. de Graaf C: Trustworthy satiety claims are good for science and society. Appetite 2011, 57:778-783.

14. Snacks: Percentages of Selected Nutrients Contributed by Foods Eaten at Snack Occasions, by Gender and Age, What We Eat in America, NHANES 2005-2006. http://www.ars.usda.gov/ba/bhnrc/fsrg.

15. de Graaf C: Effects of snacks on energy intake: an evolutionary perspective. Appetite 2006, 47:18-23.

16. Berteus Forslund H, Torgerson JS, Sjostrom L, Lindroos AK: Snacking frequency in relation to energy intake and food choices in obese men and women compared to a reference population. Int J Obes (Lond) 2005 , 29:711-719.

17. Fruit is \#1 snack food consumed by kids; the NPD group reports on top snack foods in the U.S. http://www.businesswire.com/portal/site/google/index.jsp? ndmViewld=news_view\&newsld=20050616005689\&newsLang=en

18. NPD Group: The NPD group national eating trends report to ConAgra Foods, InC.; 2009.

19. Grandjean AC, Fulgoni VL 3rd, Reimers KJ, Agarwal S: Popcorn consumption and dietary and physiological parameters of US children and adults: analysis of the National Health and Nutrition Examination Survey (NHANES) 1999-2002 dietary survey data. J Am Diet Assoc 2008, 108:853-856.

20. Stunkard AJ, Messick S: The three-factor eating questionnaire to measure dietary restraint, disinhibition and hunger. J Psychosom Res 1985, 29:71-83.

21. Stubbs RJ, Hughes DA, Johnstone AM, Rowley E, Reid C, Elia M, Stratton R, Delargy H, King N, Blundell JE: The use of visual analogue scales to assess motivation to eat in human subjects: a review of their reliability and validity with an evaluation of new hand-held computerized systems for temporal tracking of appetite ratings. Brit J Nutr 2000, 84:405-415.

22. Bell EA, Rolls BJ: Energy density of foods affects energy intake across multiple levels of fat content in lean and obese women. Am J Clin Nutr 2001, 73:1010-1018.

23. Rolls BJ, Hammer VA: Fat, carbohydrate, and the regulation of energy intake. Am J Clin Nutr 1995, 62:1086S-1095S

24. Holt SH, Miller JC, Petocz P, Farmakalidis E: A satiety index of common foods. Eur J Clin Nutr 1995, 49:675-690.

25. Anderson GH, Moore SE: Dietary proteins in the regulation of food intake and body weight in humans. J Nutr 2004, 134:974S-979S.

26. Marmonier C, Chapelot D, Fantino M, Louis-Sylvestre J: Snacks consumed in a nonhungry state have poor satiating efficiency: influence of snack composition on substrate utilization and hunger. Am J Clin Nutr 2002, 76:518-528.

27. Marmonier C, Chapelot D, Louis-Sylvestre J: Metabolic and behavioral consequences of a snack consumed in a satiety state. Am J Clin Nutr 1999, 70:854-866.

28. Zandstra EH, Stubenitsky K, De Graaf C, Mela DJ: Effects of learned flavour cues on short-term regulation of food intake in a realistic setting. Physiol Behav 2002, 75:83-90.

29. McCrory MA, Campbell WW: Effects of eating frequency, snacking, and breakfast skipping on energy regulation: symposium overview. J Nutr 2011, 141:144-147.

30. Chapelot $\mathrm{D}$ : The role of snacking in energy balance: a biobehavioral approach. J Nutr 2011, 141:158-162.

31. Howarth NC, Huang TT, Roberts SB, Lin BH, McCrory MA: Eating pattern and dietary composition in relation to BMI in younger and older adults. Int J Obes (Lond) 2007, 31:675-684.

32. Bes-Rastrollo M, Sanchez-Villegas A, Basterra-Gortari FJ, Nunez-Cordoba JM, Toledo E, Serrano-Martinez M: Prospective study of self-reported usual snacking and weight gain in a Mediterranean cohort: the SUN project. Clin Nutr 2010, 29:323-330.

33. Berteus Forslund $\mathrm{H}$, Klingstrom S, Hagberg $\mathrm{H}$, Londahl M, Torgerson JS, Lindroos AK: Should snacks be recommended in obesity treatment? A 1-year randomized clinical trial. Eur J Clin Nutr 2008, 62:1308-1317.
34. Poston WS, Haddock CK, Pinkston MM, Pace P, Karakoc ND, Reeves RS, Foreyt JP: Weight loss with meal replacement and meal replacement plus snacks: a randomized trial. Int J Obes (Lond) 2005, 29:1107-1114

35. Vander Wal JS, Waller SM, Klurfeld DM, McBurney Ml, Cho S, Kapila M, Dhurandhar NV: Effect of a post-dinner snack and partial meal replacement program on weight loss. Int J Food Sci Nutr 2006, 57:97-106.

36. Waller SM, Vander Wal JS, Klurfeld DM, McBurney MI, Cho S, Bijlani S, Dhurandhar NV: Evening ready-to-eat cereal consumption contributes to weight management. J Am Coll Nutr 2004, 23:316-321.

37. Kerver JM, Yang EJ, Obayashi S, Bianchi L, Song WO: Meal and snack patterns are associated with dietary intake of energy and nutrients in US adults. J Am Diet Assoc 2006, 106:46-53.

38. Zizza CA, Xu B: Snacking is associated with overall diet quality among adults. J Am Diet Assoc 2012, 112:291-296

doi:10.1186/1475-2891-11-71

Cite this article as: Nguyen et al:: Popcorn is more satiating than potato chips in normal-weight adults. Nutrition Journal 2012 11:71.

\section{Submit your next manuscript to BioMed Central and take full advantage of:}

- Convenient online submission

- Thorough peer review

- No space constraints or color figure charges

- Immediate publication on acceptance

- Inclusion in PubMed, CAS, Scopus and Google Scholar

- Research which is freely available for redistribution 